\title{
BEST MANAGEMENT PRACTICE UNTUK MENURUNKAN DEBIT ALIRAN DAN HASIL SEDIMEN DAS CIUJUNG MENGGUNAKAN MODEL SWAT
}

\section{Best Management Practice to Reduce Flow Discharge and Sediment Yield in Ciujung Watershed Using SWAT Model}

\section{Dede Sulaeman 1)*, Yayat Hidayat'), Latief Mahir Rachman'2), dan Suria Darma Tarigan')}

\author{
1) Alumni Program Studi Ilmu Tanah, Sekolah Pascasarjana, Institut Pertanian Bogor, Kampus IPB Dramaga, \\ Bogor 16680 \\ 2) Departemen Ilmu Tanah dan Sumberdaya Lahan, Fakultas Pertanian IPB, Jl. Meranti Kampus IPB Dramaga,
} Bogor 16680

\begin{abstract}
Ciujung Watershed is the biggest and considered as one of major watershed in Banten Province related to floods that take place almost each year in the area. The study aimed to review the SWAT (Soil and Water Assessment Tool) Model performance in predicting flow discharge and sediment yield to determine the best management practice to reduce those parameters in Ciujung Watershed. There were some steps in running SWAT model, including: (1) delineate watershed; (2) create Hydrology Respon Unit (HRU); (3) HRU definition; (4) climate data input; (5) write SWAT input files; (6) run SWAT model; (7) calibration and validation; and (8) hydrological parameters simulation. The study showed that the model had a good performance in predicting flow discharge with $R^{2}$ and NSE values in calibration process of 0.83 and 0.65 respectively. Meanwhile the model resulted not satisfied performance in predicting sediment yield with $R^{2}$ value of 0.55 and NSE value of 193.62. Validation process in predicting flow discharge produced $R^{2}$ and NSE values of 0.78 and 0.63 respectively. Land management practices used in this study are reforestation, land degradation rehabilitation, soil and water conservation practice with vegetative and mechanical method, and all land management practice implementation. The last scenario is the best management practice that can be implemented in Ciujung watershed to maintain watershed condition. The scenario produced the best river regime coefficient by 65 (moderate), reduced direct runoff and sediment yield by $46 \%$ and $95 \%$ respectively, and increased lateral and return flow by $32 \%$ and $80 \%$ respectively.
\end{abstract}

Keywords: Best management practice, flow discharge, hydrological parameters, sediment yield, SWAT model

\section{ABSTRAK}

Banjir yang terjadi hampir setiap tahun di Daerah Aliran Sungai (DAS) Ciujung menyebabkan DAS ini menjadi sorotan berbagai pihak. Penelitian ini bertujuan untuk mengkaji kinerja model SWAT untuk memprediksi debit aliran dan hasil sedimen DAS Ciujung, serta mensimulasikan parameter hidrologi untuk menurunkan debit aliran dan hasil sedimen DAS Ciujung. Dalam menjalankan model SWAT terdapat beberapa tahapan kegiatan yang dilakukan yaitu: (1) deliniasi batas DAS Ciujung, (2) pembentukan HRU, (3) pendefinisian HRU, (4) input data iklim, (5) membangun input data, (6) menjalankan model SWAT, (7) kalibrasi dan validasi model, dan (8) simulasi parameter hidrologi. Model SWAT cukup baik untuk mensimulasikan debit aliran DAS Ciujung. Hal ini dapat dilihat dari hasil kalibrasi model SWAT untuk memprediksi debit aliran yang menunjukkan nilai $\mathrm{R}^{2}$ dan NSE masing-masing sebesar 0.83 dan 0.65 (baik) serta hasil validasi model masingmasing 0.78 dan 0.63 (memuaskan). Hasil sebaliknya diperlihatkan dalam memprediksi hasil sedimen DAS Ciujung dengan nilai $\mathrm{R}^{2}$ dan NSE yang dihasilkan masing-masing sebesar 0.55 dan -193.62 (tidak memuaskan). Skenario pengelolaan lahan yang diterapkan diantaranya adalah fungsi kawasan hutan, rehabilitasi lahan kritis, teknik KTA metode vegetatif dan sipil teknis, serta skenario gabungan. Berdasarkan kemampuannya dalam menurunkan aliran permukaan, hasil sedimen, dan hasil air (water yield) serta meningkatkan aliran dasar dan aliran lateral, penerapan tindakan pengelolaan lahan gabungan merupakan pengelolaan lahan yang harus dilakukan.

Kata kunci: Skenario pengelolaan lahan, debit aliran sungai, parameter hidrologi, hasil sedimen, model SWAT

\section{PENDAHULUAN}

Banjir yang terjadi di bagian tengah dan hilir serta erosi yang terjadi di bagian hulu suatu Daerah Aliran Sungai (DAS) merupakan salah satu indikasi bahwa fungsi hidrologis DAS dalam keadaan terganggu sehingga DAS tersebut tidak dapat mendukung sistem tata air yang optimal. Banjir di DAS Ciujung kerap kali terjadi, bahkan sudah mulai menjadi fenomena yang rutin terjadi setiap tahunnya. Menurut Sukardi et al. (2013) banjir di daerah ini telah terjadi sebanyak tujuh kali sejak tahun 1996. 
Deforestasi yang terjadi di bagian hulu dan sepanjang aliran sungai, erosi hebat yang terjadi selama musim penghujan, pendangkalan sungai terkait dengan sedimentasi, serta daerah permukiman yang padat di bantaran sungai merupakan penyebab terjadinya banjir di DAS Ciujung. Laju sedimentasi di DAS Ciujung sebesar $2.5 \mathrm{~mm}$ per tahun yang dikategorikan buruk dimana laju sedimentasi melebihi $2 \mathrm{~mm}$ per tahun. Menurut Balai Besar Wilayah Sungai Cidanau-Ciujung-Cidurian (BBWS C3) yang melakukan pemeriksaan pada awal tahun 2013 sedimentasi di Bendung Pamarayan cukup parah yakni $10 \%$ dari kapasitas bendung. Koefisien regim sungai yang membandingkan debit maksimum dan minimum DAS Ciujung sebesar 189 atau jauh di atas 80. Indikatorindikator tersebut mengindikasikan bahwa DAS Ciujung berada pada kondisi kritis (Sukardi et al., 2013).

Sebagaimana terdapat pada Rencana Teknik Rehabilitasi Hutan dan Lahan (RTk-RHL) DAS Ciujung, terdapat $8.3 \%$ lahan kritis dan $56.5 \%$ potensial kritis. Lahan kritis tersebut sebagian besar disebabkan oleh konversi lahan menjadi permukiman, industri, dan perkebunan (terutama singkong dan kelapa sawit), serta tindakan pengelolaan lahan yang kurang baik.

Keutuhan dan kemantapan fungsi DAS Ciujung sangat berpengaruh terhadap beberapa Kabupaten/Kota di Provinsi Banten seperti Kabupaten Lebak, Kabupaten Serang dan Kabupaten/Kota Tangerang khususnya berkaitan dengan sering terjadinya banjir di wilayah DAS Ciujung. Selain itu DAS Ciujung berfungsi sebagai daerah tangkapan air yang akan diarahkan untuk mensuplai air bagi Bendungan Karian. Tidak mengherankan jika Balai Pengelolaan DAS Ciliwung Cisadane dan Balai Besar Wilayah Sungai Cidanau-Ciujung-Cidurian (BBWS C3) menjadikan DAS Ciujung sebagai prioritas utama dalam pengelolaan daerah aliran sungai di Provinsi Banten.

Fenomena memburuknya kondisi hidrologi DAS Ciujung perlu dipahami guna menentukan tindakan yang perlu dilakukan di masa yang akan datang. Model merupakan alat yang dapat membantu memahami fenomena tersebut. Salah satu model yang dapat digunakan adalah Soil and Water Assessment Tool (SWAT). Dengan menggunakan model ini, diharapkan dapat diketahui pengelolaan lahan terbaik yang dapat menurunkan debit aliran dan hasil sedimen DAS Ciujung.

Penelitian ini bertujuan untuk: (1) mengkaji kinerja model SWAT untuk memprediksi debit aliran dan hasil sedimen DAS Ciujung; dan (2) mensimulasikan parameter hidrologi untuk menurunkan debit aliran dan hasil sedimen DAS Ciujung.

\section{BAHAN DAN METODE}

Penelitian dilaksanakan mulai bulan Februari sampai Desember 2014 di Daerah Aliran Sungai (DAS) Ciujung yang terletak di $5^{\circ} 57^{\prime} 14^{\prime \prime} L S-6^{\circ} 4$ '20" LS dan $106^{\circ} 01^{\prime} 00^{\prime \prime} \mathrm{BT}-106^{\circ} 29^{\prime} 03^{\prime \prime}$ BT dengan luas $\pm 190,635.6$ ha. Wilayah DAS Ciujung dibatasi oleh laut Jawa di bagian utara; DAS Rawa, Cidano dan Teluk Lada di bagian barat; DAS Cidurian di bagian timur; serta DAS Cibaliung-Cibareno di bagian selatan.

Bahan yang digunakan dalam penelitian ini di antaranya data sekunder berupa debit aliran sungai dan data iklim (curah hujan, suhu udara maksimum dan minimum, kecepatan angin, kelembaban udara dan radiasi matahari) tahun 2008-2012. Berbagai jenis peta digunakan dalam penelitian ini diantaranya peta penggunaan lahan tahun 2011 dan 2012 skala 1:250,000, peta jenis tanah skala 1:250,000, serta peta DEM (Digital Elevation Model) resolusi $30 \times 30 \mathrm{~m}$.

Peralatan yang digunakan adalah: (1) seperangkat komputer dengan perangkat lunak ArcGIS 10.1 dan ArcSWAT 2012 (versi 10.1.14) sebagai interface, pcpSTAT, SWAT Plot, SWAT BFlow, serta SWAT CUP; (2) Global Positioning System (GPS); (3) ring sampler ; (4) double ring infiltrometer dan alat-alat lainnya yang diperlukan untuk pengambilan sampel fisik tanah dan analisis di laboratorium.

\section{Prosedur Penelitian}

Penelitian dilaksanakan dalam tiga tahapan. Tahap pertama yaitu pengumpulan data sekunder. Tahap kedua adalah pengambilan dan analisis contoh tanah untuk input data tanah pada model SWAT. Tahap terakhir adalah menjalankan model SWAT yang terbagi ke dalam beberapa tahapan tersendiri yaitu: (1) Deliniasi DAS; (2) Analisis Hydrology Respones Unit (HRU); (3) Input data iklim; (4) Membangun data iklim; (5) Run model; (6) Kalibrasi dan validasi; serta (7) Simulasi parameter hidrologi.

Metode statistik yang digunakan dalam melakukan kalibrasi adalah koefisien determinasi $\left(\mathrm{R}^{2}\right)$ dan NashSutcliffe Efficiency (NSE). Nilai $\mathrm{R}^{2}$ dapat dikalkulasikan menggunakan rumus:

$$
R^{2}=\frac{(O-\bar{O})^{2}-(O-P)^{2}}{(O-\bar{O})^{2}}
$$

dimana $O$ adalah data observasi, $\bar{O}$ adalah data observasi rata-rata, dan $\mathrm{P}$ adalah data simulasi. Pada dasarnya nilai $\mathrm{R}^{2} \geq 0.5$ dianggap dapat diterima (Moriasi et al., 2007). Adapun persamaan dari model efisiensi Nash-Sutcliffe Efficiency (NSE) adalah sebagai berikut:

$$
\mathrm{NSE}=1-\left[\frac{\sum_{i=1}^{n}\left(Y_{i}^{a b s}-Y_{i}^{s i m}\right)^{2}}{\sum_{i=1}^{n}\left(Y_{i}^{a b s}-\bar{Y}^{a b s}\right)^{2}}\right]
$$

dimana $Y_{i}^{\text {obs }}$ merupakan data observasi ke-i, $Y_{i}^{\text {sim }}$ merupakan data simulasi ke-i, $\bar{Y}^{\text {obs }}$ merupakan data observasi rata-rata, dan $\mathrm{n}$ merupakan jumlah observasi (Tabel 1).

Tabel 1. Tingkat performa model NSE

\begin{tabular}{ll}
\hline \multicolumn{1}{c}{ Tingkat Performa } & \multicolumn{1}{c}{ NSE } \\
\hline Sangat baik & $0.75 \leq \mathrm{NSE} \leq 1.00$ \\
Baik & $0.65 \leq \mathrm{NSE} \leq 0.75$ \\
Memuaskan & $0.50 \leq \mathrm{NSE} \leq 0.65$ \\
Tidak memuaskan & $\mathrm{NSE} \leq 0.50$ \\
\hline Sumber: Moriasi et al. $(2007)$ &
\end{tabular}

Sumber: Moriasi et al. (2007) 


\section{Rancangan Skenario Pengelolaan Lahan}

\section{Fungsi Kawasan Hutan}

Skenario 1 diterapkan berdasarkan fungsi kawasan hutan di DAS Ciujung. Simulasi parameter hidrologi yang diterapkan di antaranya adalah $\mathrm{CN} 2$ (curve number), SOL_K (permeabilitas tanah), SOL_C (bahan organik tanah), dan SOL_BD (bobot isi tanah). Nilai-nilai parameter yang diterapkan tersebut mengacu pada hasil penelitian Prasetya et al. (2012).

\section{Rehabilitasi Lahan Kritis}

Pengelolaan lahan yang diterapkan pada skenario 2 diantaranya melakukan reboisasi pada lahan kritis di seluruh penggunaan lahan kecuali permukiman. Agroforestry diterapkan pada lahan agak kritis dengan penggunaan lahan eksisting berupa pertanian lahan kering, pertanian lahan kering campur semak, perkebunan, dan semak belukar. Simulasi parameter hidrologi yang diterapkan pada skenario 2 ini diantaranya adalah CN2, SOL_K, SOL_C, SOL_BD, dan SOL_AWC (kadar air tersedia). Nilai parameter yang digunakan mengacu pada hasil penelitian Prasetya et al. (2012).

\section{Penerapan Teknik Konservasi Tanah dan Air Metode Vegetatif}

Penerapan teknik KTA metode vegetatif yang diterapkan diantaranya strip cropping pada areal pertanian lahan kering dan pertanian lahan kering campur semak dengan kemiringan $0-25 \%$, sedangkan pada kemiringan $25-40 \%$ diterapkan agroforestry. Seluruh penggunaan lahan dengan kemiringan $>40 \%$ dilakukan reboisasi. Parameter hidrologi yang disimulasikan pada skenario 3 ini diantaranya adalah $\mathrm{CN} 2$, SOL_K, SOL_BD, SOL_AWC, STRIP_CN (bilangan kurva aliran permukaan untuk strip cropping), STRIP_P (faktor P USLE untuk strip cropping), STRIP_C (faktor C USLE), dan STRIP_N (nilai koefisien kekasaran Manning). Nilai-nilai tersebut mengacu pada Williams et al. (1990) dalam Wang et al. (2011); Wischmeier dan Smith (1978) dalam Arabi et al. (2007); Kuok et al. (2013), dan Engman (1983) dalam Arnold et al. (2012).

\section{Penerapan Teknik Konservasi Tanah dan Air Metode Sipil Teknis}

Teknik KTA metode sipil teknis diterapkan sebagai skenario 4. Teknik KTA sipil teknis berbasis alur yang diterapkan adalah bendungan karian yang terdapat dalam Rencana Tata Ruang Wilayah (RTRW) Provinsi Banten. Kegiatan sipil teknis berbasis lahan yang digunakan diantaranya penanaman sesuai kontur (contouring) pada penggunaan lahan pertanian lahan kering, pertanian lahan kering campur dan perkebunan pada kemiringan lereng $0-8$ dan $8-15 \%$, serta penerapan Lubang Resapan Biopori (LRB) pada lahan permukiman.

Parameter hidrologi yang disimulasikan diantaranya adalah RES_VOL (volume bendungan), RES_EVOL (emergency spillway) dan RES_PVOL (principal spillway) untuk simulasi bendungan. Nilai tersebut ditetapkan berdasarkan data sekunder yang didapatkan dari Balai Pengelolaan Sumberdaya Air (BPSDA) Ciujung-Cidanau.
Parameter CONT_P (nilai P USLE untuk contouring) dan CONT_CN (bilangan kurva untuk contouring) untuk simulasi penanaman sesuai kontur serta CN2, SOL_BD, dan SOL_K untuk simulasi Lubang Resapan Biopori (LRB). Nilai-nilai parameter tersebut mengacu pada Wischmeier and Smith (1978) dalam Arabi et al. (2007); USDA-NRCS (2004) dan Williams et al. (1990) dalam Wang et al. (2011); dan Maharany et al. (2011) (Tabel 2).

Tabel 2. Skenario pengelolaan lahan dan simulasi parameter hidrologi yang diterapkan

\begin{tabular}{|c|c|c|c|c|}
\hline \multirow[b]{2}{*}{ Skenario } & \multirow{2}{*}{$\begin{array}{c}\text { Simulasi Parameter } \\
\text { Hidrologi }\end{array}$} & \multirow{2}{*}{$\begin{array}{c}\text { Lokasi } \\
\text { Simulasi } \\
\text { (Sub DAS) } \\
\end{array}$} & \multicolumn{2}{|c|}{ Luas } \\
\hline & & & ha & $\%$ \\
\hline 1 & $\begin{array}{l}\text { CN2, SOL_K, SOL_C, } \\
\text { dan SOL_BD }\end{array}$ & $\begin{array}{c}4,7,9,10,11, \\
13-18,21, \text { dan } \\
20\end{array}$ & 17,333 & 12 \\
\hline 2 & $\begin{array}{l}\text { CN2, SOL_K, SOL_C, } \\
\text { SOL_BD, dan } \\
\text { SOL_AWC }\end{array}$ & $\begin{array}{l}1,2,5,6,7,10- \\
21\end{array}$ & 42,946 & 30 \\
\hline 3 & $\begin{array}{l}\text { CN2, SOL_K, } \\
\text { SOL_BD, SOL_AWC, } \\
\text { STRIP_CN, STRIP_P, } \\
\text { STRIP_C, dan } \\
\text { STRIP_N }\end{array}$ & $1,2,4-7,9-21$ & 40,202 & 28 \\
\hline 4 & $\begin{array}{l}\text { RES_VOL, } \\
\text { RES_EVOL, } \\
\text { RES_PVOL, } \\
\text { CONT_P, CONT_CN, } \\
\text { CN2, SOL_BD, dan } \\
\text { SOL_K }\end{array}$ & $1,2,4-7,9-21$ & 47,954 & 34 \\
\hline 5 & Semua & $1,2,4-7,9-21$ & 66,390 & 47 \\
\hline
\end{tabular}

Perubahan nilai-nilai parameter ini mengikuti teknik pengelolaan lahan yang diterapkan pada masingmasing skenario.

\section{Penerapan Semua Skenario}

Pengelolaan lahan yang diterapkan pada skenario 5 meliputi penerapan fungsi kawasan hutan, rehabilitasi lahan kritis, teknik KTA metode vegetatif, dan teknik KTA metode mekanik yang diterapkan secara bersamaan.

\section{HASIL DAN PEMBAHASAN}

\section{Kalibrasi Model}

Kalibrasi bertujuan untuk menyesuaikan parameter model agar sesuai dengan kondisi lapang, sehingga mengurangi ketidakpastian prediksi. Telah banyak studi yang menjelaskan mengenai parameter yang digunakan dalam proses kalibrasi pada model SWAT. Walaupun demikian, parameter yang digunakan sangat bervariasi tergantung dari pendekatan yang digunakan dan lokasi penelitian (Feyereisen et al., 2007).

Parameter yang digunakan dalam proses kalibrasi yaitu bilangan kurva aliran permukaan (CN), kedalaman permukaan air awal pada aquifer dangkal (SHALLST), koefisien lag aliran permukaan (SURLAG), batas kedalaman air pada aquifer dangkal yang dibutuhkan untuk kembali terjadinya aliran (GWQMN), faktor kompensasi evaporasi tanah (ESCO), fraksi perkolasi akuifer dalam (RCHRG_DP), faktor alpha baseflow untuk "bank storage" (ALPHA_BNK), koefisien "revap" air bawah tanah (GW_REVAP), faktor kompensasi uptake 
tanaman (EPCO), koefisien kekasaran Manning untuk saluran utama (CH_N(2)), konduktifitas hidrolik efektif pada saluran utama $\left(\mathrm{CH}_{-} \mathrm{K}(2)\right)$, faktor alpha baseflow (ALPHA_BF), nilai koefisien Manning (OV_N), waktu delay air bawah tanah (GW_DELAY), dan batas kedalaman air pada aquifer dangkal untuk "revap" atau perkolasi ke aquifer dalam (REVAPMN). Pemilihan parameter tersebut mengacu pada Arnold et al. (2012). Nilai pertama yang digunakan dalam proses kalibrasi ditetapkan berdasarkan pengamatan lapang dan data sekunder. Selanjutnya dilakukan dengan memilih nilainilai untuk input parameter model dengan membandingkan data prediksi model (output) dan data observasi secara manual dan otomatis menggunakan SWAT-CUP. Nilai awal dan nilai hasil proses kalibrasi dapat dilihat pada Tabel 3.

Tabel 3. Parameter yang digunakan dalam proses kalibrasi debit aliran

\begin{tabular}{clcccc}
\hline No & Parameter & Satuan & Nilai Min & $\begin{array}{c}\text { Nilai } \\
\text { Max }\end{array}$ & $\begin{array}{c}\text { Nilai yang } \\
\text { digunakan }\end{array}$ \\
\hline 1 & CN2 & $\%$ & 35 & 92 & $35-94^{* *}$ \\
2 & SHALLST & mm & 1000 & 5000 & 4000 \\
3 & SURLAG & hari & 1 & 4 & 2 \\
4 & GWQMN & mm & 1000 & 4000 & 3500 \\
5 & ESCO & - & 0.6 & 0.98 & 0.85 \\
6 & RCHRG_DP & - & 0.05 & 0.25 & 0.1 \\
7 & ALPHA_BNK & - & 0.2 & 0.9 & 0.55 \\
8 & GW_REVAP & - & 0.02 & 0.2 & $0.02-0.1 * *$ \\
9 & EPCO & - & 0.5 & 0.8 & 0.56 \\
10 & CH_N(2) & - & 0.02 & 0.1 & $0.04-0.1 *$ \\
11 & CH_K(2) & mm jam & 0.001 & 0.025 & $0.004-0.025^{*}$ \\
12 & ALPHA_BF & - & 0.1 & 1 & 0.52 \\
13 & OV_N & - & 0.01 & 0.48 & $0.011-0.41^{* *}$ \\
14 & GW_DELAY & hari & 15 & 80 & 65 \\
15 & REVAPMN & mm & 350 & 1000 & 500 \\
\hline Ket: & nilaiberbeda berdasarkan sub DAS & &
\end{tabular}

Ket: * nilai berbeda berdasarkan sub DAS

** nilai berbeda berdasarkan penggunaan lahan

Data observasi yang digunakan untuk kalibrasi adalah data harian pada bulan Januari-September 2011 dari outlet Jembatan II Rangkas. Gan et al. (1997) dalam Arnold et al. (2012) menyarankan untuk melibatkan data dari periode basah dan periode kering pada proses kalibrasi maupun validasi.

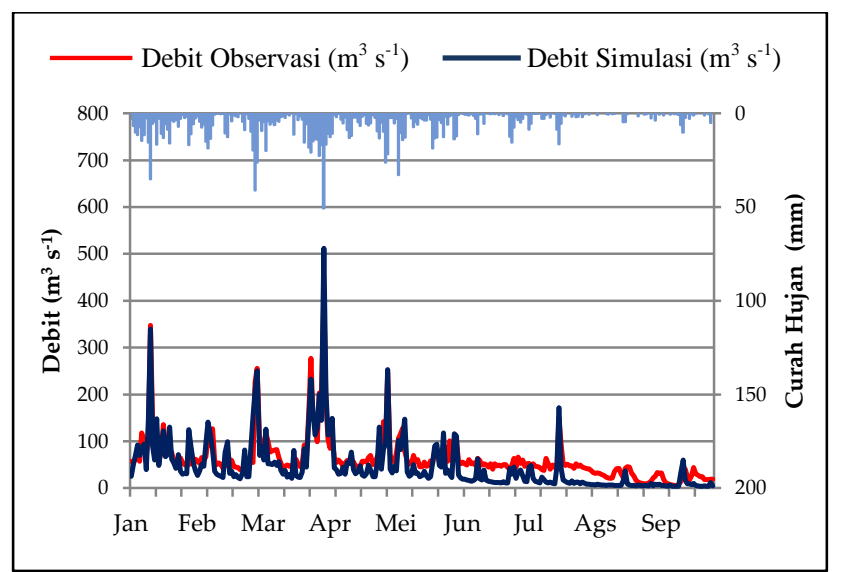

Gambar 1. Hidrograf aliran hasil kalibrasi model (JanuariSeptember 2011)

Hasil output model menunjukkan nilai $\mathrm{R}^{2}$ dan NSE masing-masing sebesar 0.83 dan 0.65 (baik) setelah digunakan parameter-parameter hasil kalibrasi. Nilai
$\mathrm{R}^{2} \geq 0.6$ dan $\mathrm{NSE} \geq 0.5$ merupakan nilai yang dapat diterima (Santhi et al., 2001). Hasil ini menunjukkan bahwa model SWAT cukup baik untuk mensimulasikan debit aliran sungai di DAS Ciujung (Gambar 1 dan 2).

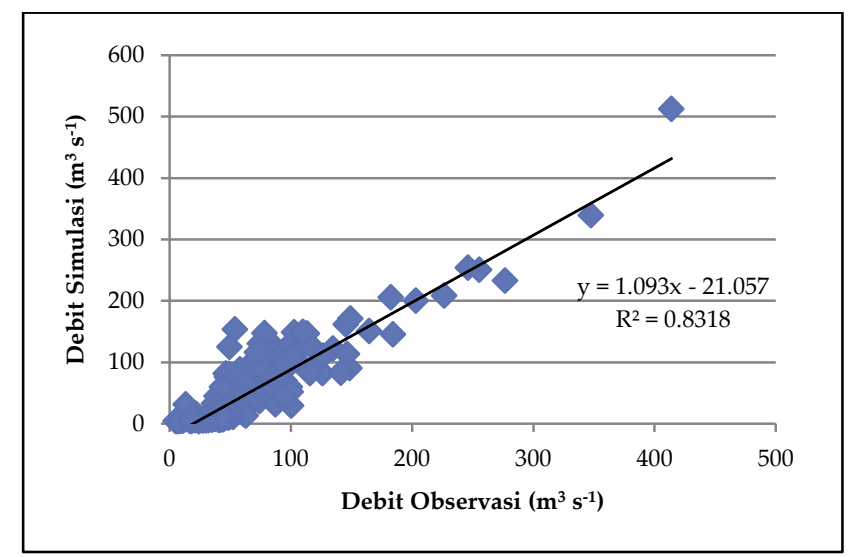

Gambar 2. Debit aliran harian simulasi dan observasi setelah proses kalibrasi

\section{Validasi Model}

Validasi model bertujuan untuk menguji konsistensi model. Validasi dilakukan dengan menjalankan model menggunakan parameter yang telah ditentukan selama proses kalibrasi serta membandingkan data prediksi dan data observasi yang tidak digunakan dalam proses kalibrasi.

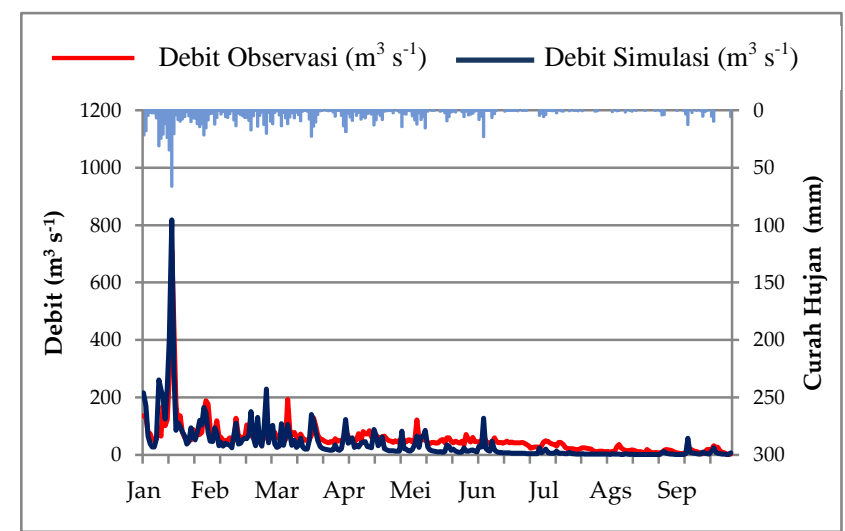

Gambar 3. Hidrograf aliran hasil validasi model (JanuariSeptember 2012)

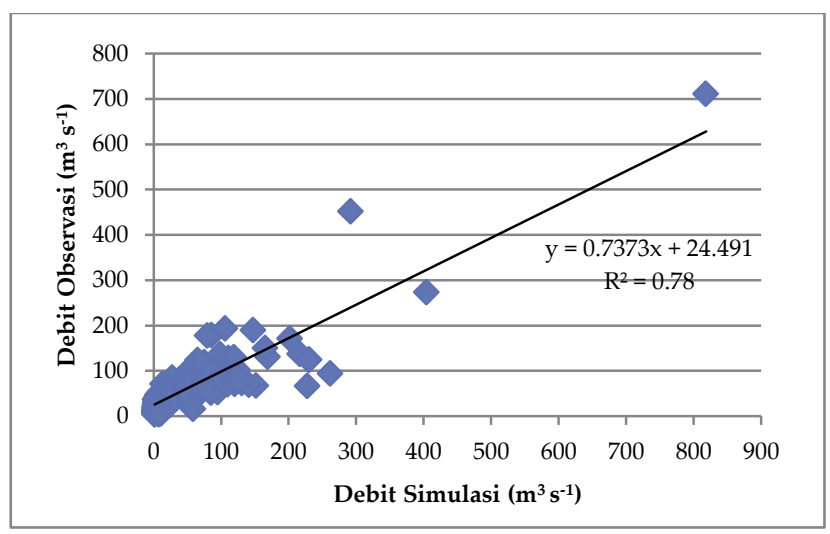

Gambar 4. Debit aliran harian simulasi dan observasi setelah proses validasi 
Data observasi yang digunakan untuk validasi adalah data harian pada bulan Januari-September 2012 dari outlet Jembatan II Rangkas. Nilai $\mathrm{R}^{2}$ dan NSE yang dihasilkan pada proses validasi masing-masing sebesar 0.78 dan 0.63 (baik) (Gambar 3 dan 4).

\section{Hasil Sedimen}

Hasil sedimen observasi didapatkan dengan cara membuat rating curve sedimen menggunakan data harian pada bulan Februari-Desember 2013. Data hasil sedimen tersebut dibandingkan dengan data debit aliran untuk mendapatkan persamaan yang digunakan untuk membuat rating curve hasil sedimen observasi. Persamaan yang didapat adalah $\mathrm{y}=1.5702 \times 1.768$ dengan nilai koefisien determinasi sebesar 0.85 . Hasil sedimen harian didapatkan dengan cara mengganti nilai $\mathrm{x}$ dengan nilai debit aliran sungai harian.

Hubungan antara hasil sedimen observasi dan simulasi menunjukkan nilai $\mathrm{R}^{2}$ dan NSE masing-masing sebesar 0.76 dan -193.62. Nilai tersebut menunjukkan bahwa hasil sedimen simulasi tidak dapat menggambarkan hasil sedimen observasi DAS Ciujung dengan baik. Hal ini dikarenakan kurangnya data observasi. Model SWAT tidak dapat menggambarkan proses secara akurat karena kurangnya data pemantauan yang diperlukan untuk mengkarakterisasi parameter input (Gassman et al., 2007) (Gambar 5 dan 6).

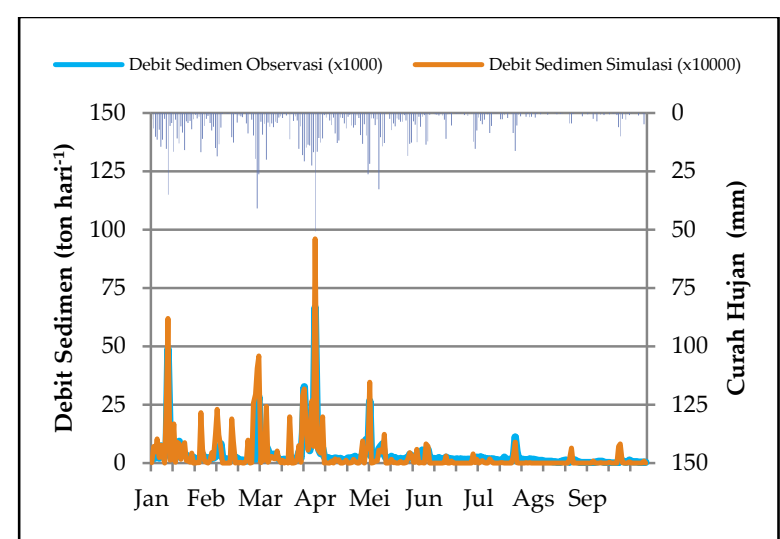

Gambar 5. Hidrograf debit sedimen observasi dan simulasi (Januari-September 2011)

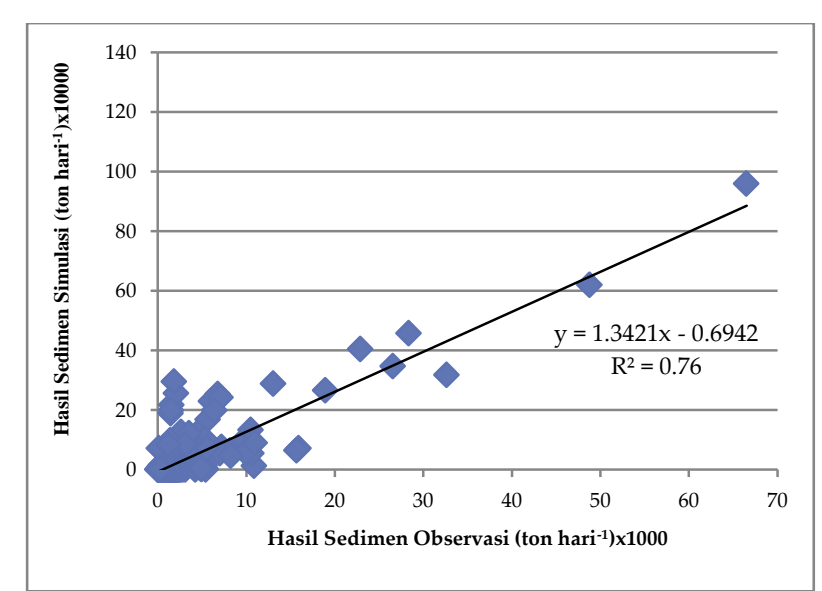

Gambar 6. Debit sedimen harian observasi dan simulasi (Januari-September 2011)

\section{Rekomendasi Pengelolaan Lahan}

Pengelolaan lahan yang kurang baik dan tidak sesuai dengan kaidah konservasi tanah dan air seringkali menjadi penyebab tingginya aliran permukaan yang dihasilkan pada suatu lahan. Ketebalan aliran permukaan yang dihasilkan pada setiap sub DAS menjadi bahan pertimbangan diterapkannya skenario pengelolaan lahan di DAS Ciujung. Hasil output model menunjukkan bahwa pada tahun 2011 sub DAS 14, 19, 20, dan 21 memiliki aliran permukaan yang paling tinggi jika dibandingkan dengan sub DAS yang lainnya dengan ketebalan $>1000$ $\mathrm{mm}$. Sub DAS 3, 8, 22, 23, 24, 25, dan 26 memiliki ketebalan aliran permukaan yang paling rendah $(<500$ $\mathrm{mm})$. Sub DAS lainnya memiliki ketebalan aliran permukaan antara 500-1000 $\mathrm{mm}$.

Skenario pengelolaan lahan hanya diterapkan pada sub DAS-sub DAS yang memiliki ketebalan aliran permukaan 500-1000 dan >1000 mm. Beberapa parameter yang diperhitungkan dalam menentukan pengelolaan lahan yang harus dilakukan untuk mempertahankan kondisi DAS Ciujung diantaranya adalah debit aliran sungai, aliran permukaan, aliran lateral, aliran dasar, hasil air, dan hasil sedimen (Gambar 7).

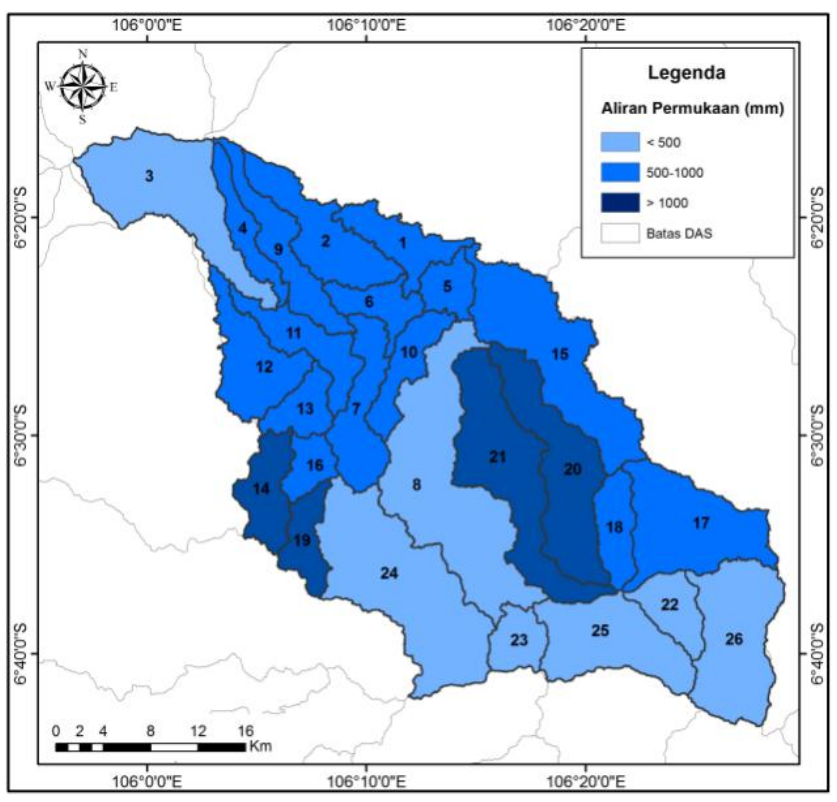

Gambar 7. Aliran permukaan pada setiap sub DAS

\section{Debit Aliran Sungai}

Membaiknya fungsi hidrologi tanah setelah dilakukan tindakan penanggulangan diperlihatkan dengan menurunnya debit maksimum (Qmax) dan meningkatnya debit mínimum (Qmin). Semakin besar nisbah Qmax/Qmin menandakan kondisi DAS semakin buruk, sebaliknya semakin kecil nilainya maka kondisi DAS semakin baik. Kondisi paling baik dihasilkan skenario 5 dengan nilai Qmax/Qmin sebesar 65 (sedang). Skenario 1, 2, dan 3, masing-masing menghasilkan nisbah sebesar 148, 109, dan 157 dengan kondisi jelek serta skenario 4 sebesar 91 (sedang) (Tabel 4). 
Tabel 4. Kondisi DAS Ciujung pada tahun 2011

\begin{tabular}{lcccccc}
\hline \multicolumn{1}{c}{ Debit $\left(\mathrm{m}^{3} \mathrm{~s}^{-1}\right)$} & Tanpa Skenario & Skenario 1 & Skenario 2 & Skenario 3 & Skenario 4 & Skenario 5 \\
\hline $\mathrm{Q}_{\max }$ & 511.9 & 493.1 & 480.0 & 512.4 & 457.0 & 431.3 \\
$\mathrm{Q}_{\min }$ & 2.6 & 3.3 & 4.4 & 3.3 & 5.0 & 6.7 \\
$\mathrm{Q}_{\max } / \mathrm{Q}_{\min }$ & 198 & 148 & 109 & 157 & 91 & 65 \\
Kategori & $\mathrm{J}$ & $\mathrm{J}$ & $\mathrm{J}$ & $\mathrm{J}$ & $\mathrm{S}$ & $\mathrm{S}$ \\
\hline
\end{tabular}

Keterangan : B: Baik; S : Sedang; J : Jelek; berdasarkan Direktorat Jenderal Rehabilitasi Lahan dan Perhutanan Sosial (Ditjen RLPS)

\section{Aliran Permukaan, Aliran Lateral, Aliran Dasar, dan Hasil Air}

Hasil penelitian menunjukkan bahwa skenarioskenario yang diterapkan dapat menurunkan aliran permukaan (SURQ) dan hasil air (WYLD), serta meningkatkan aliran lateral (LATQ) dan aliran dasar (GWQ) (Tabel 5).
Dalam hal meningkatkan aliran lateral dan aliran dasar, skenario 5 memiliki kemampuan yang lebih baik daripada skenario lainnya. Aliran lateral dan aliran dasar meningkat sebesar 32 dan $80 \%$ setelah diterapkan skenario 5. Meningkatnya aliran lateral dan aliran dasar merupakan kriteria penting yang dapat diperhitungkan dalam menentukan pengelolaan lahan terbaik yang akan diterap-

Tabel 5. Karakteristik hidrologi DAS Ciujung pada berbagai skenario yang diterapkan pada tahun 2011

\begin{tabular}{|c|c|c|c|c|c|c|c|c|c|c|c|c|c|}
\hline \multirow{2}{*}{ Skenario } & \multirow{2}{*}{$\begin{array}{c}\mathrm{CH} \\
\mathrm{mm}\end{array}$} & \multirow{2}{*}{$\begin{array}{c}\text { SURQ } \\
\mathrm{mm}\end{array}$} & \multicolumn{2}{|c|}{$\Delta$ SURQ } & \multirow{2}{*}{$\begin{array}{c}\text { LATQ } \\
\mathrm{mm}\end{array}$} & \multicolumn{2}{|c|}{$\Delta$ LATQ } & \multirow{2}{*}{$\begin{array}{c}\text { GWQ } \\
\mathrm{mm}\end{array}$} & \multicolumn{2}{|c|}{$\Delta$ GWQ } & \multirow{2}{*}{$\begin{array}{c}\text { WYLD } \\
\mathrm{mm}\end{array}$} & \multicolumn{2}{|c|}{$\Delta \mathrm{WYLD}$} \\
\hline & & & $\mathrm{mm}$ & $\%$ & & $\mathrm{~mm}$ & $\%$ & & $\mathrm{~mm}$ & $\%$ & & $\mathrm{~mm}$ & $\%$ \\
\hline Tanpa Skenario & 1,873 & 575 & - & - & 236 & - & - & 211 & - & - & 1049 & - & - \\
\hline Skenario 1 & 1,873 & 487 & -87 & -15 & 276 & 39 & 19 & 218 & 7 & 3 & 997 & -52 & -5 \\
\hline Skenario 3 & 1,873 & 515 & -60 & -10 & 262 & 26 & 12 & 204 & 7 & 3 & 996 & -53 & -5 \\
\hline Skenario 4 & 1,873 & 393 & 182 & -32 & 288 & 52 & 22 & 240 & 29 & 1 & 925 & -124 & -12 \\
\hline Skenario 5 & 1,873 & 308 & -267 & -46 & 304 & 68 & 32 & 379 & 168 & 80 & 886 & -163 & -16 \\
\hline
\end{tabular}

Keterangan: $\Delta$ : perbandingan nilai hasil skenario yang diterapkan dengan tanpa skenario

\section{Hasil Sedimen}

Hasil penelitian menunjukkan bahwa skenario 5 merupakan skenario yang paling baik dalam menurunkan aliran permukaan yaitu sebesar $46 \%$ jika dibandingkan dengan tanpa skenario. Hal ini diikuti dengan menurunnya hasil sedimen sebesar 95\% (Tabel 6).

Tabel 6. Penurunan hasil sedimen setelah diterapkan skenario pengelolaan lahan

\begin{tabular}{cccc}
\hline \multirow{2}{*}{ Skenario } & \multirow{2}{*}{ Hasil sedimen $\left(\right.$ ton hari $\left.{ }^{-1}\right)$} & \multicolumn{2}{c}{ Penurunan hasil sedimen } \\
\cline { 3 - 4 } & & ton hari $^{-1}$ & $\%$ \\
\hline Tanpa skenario & 47,966 & - & - \\
Skenario 1 & 32,686 & 15,280 & 32 \\
Skenario 2 & 11,422 & 36,544 & 76 \\
Skenario 3 & 33,915 & 14,051 & 29 \\
Skenario 4 & 8,154 & 39,812 & 83 \\
Skenario 5 & 2,510 & 45,456 & 95 \\
\hline
\end{tabular}

Berdasarkan kemampuannya dalam menurunkan debit maksimum dan meningkatkan debit minimum, skenario 5 merupakan pengelolaan lahan terbaik yang dapat diterapkan di DAS Ciujung. Hal ini diperlihatkan dengan nisbah Qmax/Qmin yang paling kecil. Kecilnya nisbah debit maksimum dan debit minimum menggambarkan keberlangsungan aliran sungai dapat dijaga sepanjang tahun. Skenario 5 juga memiliki kemampuan yang paling baik dalam menurunkan aliran permukaan (46\% dari aliran permukaan tanpa skenario). Hasil ini lebih baik dari skenario $4(32 \%)$, skenario 2 (30\%) serta skenario 1 dan 3 yang hanya dapat menurunkan aliran permukaan sebesar 15 dan $10 \%$. kan. Hal ini dikarenakan aliran inilah yang akan menyuplai aliran sungai pada saat musim kemarau tiba.

Skenario 5 merupakan skenario terbaik dengan penurunan hasil sedimen mencapai $95 \%$. Sedimentasi pada badan air merupakan masalah serius yang dimiliki DAS Ciujung. Semakin banyaknya sedimen yang memenuhi badan air maka kapasitas menampung air dapat berkurang karena terjadi pendangkalan. Hal ini merupakan salah satu pemicu terjadinya banjir.

Berdasarkan kemampuannya dalam menurunkan aliran permukaan, hasil sedimen, dan hasil air (water yield) serta meningkatkan aliran dasar dan aliran lateral, skenario 5 merupakan pengelolaan lahan terbaik yang dapat diterapkan di DAS Ciujung.

\section{SIMPULAN}

Model SWAT cukup baik dalam memprediksi debit aliran sungai, dan sebaliknya untuk hasil sedimen. Penerapan fungsi kawasan hutan, rehabilitasi lahan kritis, teknik KTA metode vegetatif dan sipil teknis dengan menerapkan seluruh simulasi parameter hidrologi merupakan pengelolaan lahan yang harus dilakukan untuk memperbaiki kondisi DAS Ciujung.

\section{DAFTAR PUSTAKA}

Arabi, M., J.R. Frankenberger, B.A. Engel, and J.G. Arnold. 2007. Representation of agricultural conservation practices with SWAT. J. Hydrol. Process., 22: 3042-3055. 
Arnold, J.G., D.N. Moriasi, P.W. Gassman, K.C. Abbaspour, M.J. White, R. Srinivasan, C. Santhi, R.D. Harmel, A.V. Griensven, M.W.V. Liew, N. Kannan, and M.K. Jha. 2012. SWAT: model use, calibration, and validation. J. American Society of Agricultural and Biological Engineers, 55: 14911508.

Feyereisen, G.W., T.C. Strickland, D.D. Bosch, and D.G. Sullivan. 2007. Evaluation of SWAT manual calibration and input parameter sensitivity in the little river watershed. J. American Society of Agricultural and Biological Engineers, 50: 843-855.

Gassman, P.W., M.R. Reyes, C.H. Green, and J.G. Arnold. 2007. The soil and water assessment tool: historical development, applications, and future research directions. J. American Society of Agricultural and Biological Engineers, 50: 1211-1250.

Kuok, K., D.Y.S. Mah, and P.C. Chiu. 2013. Evaluation of $\mathrm{C}$ and $\mathrm{P}$ factors in Universal Soil Loss Equation on trapping sediment: case study of Santubong River. J. Water Resource and Protection, 5: 1149-1154.

Maharany, R., A. Rauf, and T. Sabrina. 2011. Perbaikan sifat tanah kebun Kakao pada berbagai kemiringan lahan dengan menggunakan teknik biopori dan mulsa vertikal. J. Ilmu Pertanian KULTIVAR, 5: 75-82.
Moriasi, D.N., J.G. Arnold, M.W.V. Liew, R.L. Bingner, R.D. Harmel, and T.L. Veith. 2007. Model evaluation guidelines for systematic quantification of accuracy in watershed simulations. J. American Society of Agricultural and Biological Engineers, 50: 885-900.

Prasetya, B., S. Prijono, dan Y. Widjiawati. 2012. Vegetasi pohon hutan memperbaiki kualitas tanah andisolNgabab. J. Indonesian Green Technology, 1: 1-6.

Santhi, C., J.G. Arnold, J.R. Williams, W.A. Dugas, R. Srinivasan, and L.M. Hauck. 2001. Validation of the SWAT model on a large river basin with point an nonpoint sources. Journal of The American Water Resources Association, 37: 1169-1188.

Sukardi, S., B. Warsito, H. Kisworo, and Sukiyoto. 2013. River Management in Indonesia. Directorate General of Water Resources. Yayasan Air Adhi Eka, and Japan International Cooperation Agency, Jakarta.

Wang, X., N. Kannan, C. Santhi, S.R. Potter, J.R. Williams, and J.G. Arnold. 2011. Integrating APEX output for cultivated cropland with SWAT simulation for regional modeling. J. American Society of Agricultural and Biological Engineers, 54: 1281-1298. 